\author{
Miten ihminen hahmottaa elämänsä eri vaiheita? Mitä merkityksiä hän \\ antaa kohtalokkaille kokemuksilleen? Miten kokemukset vaikuttavat \\ minuuden muotoutumiseen ja omaan elämänkertomukseen? Artikkelissa \\ nostetaan keskusteluun aikuisen ihmisen tarpeet ymmärtää omaa \\ minuuttaan, henkistä kasvuaan ja itsessään tapahtuvia muutoksia.
}

\title{
CAMILLA KOVERO
}

$\mathrm{L}$ änsimaisessa informaatio- ja tietoyhteiskunnassa on aikuiskasvatuksellisiin kysymyksiin kiinnitetty yhä enemmän huomiota. Yhteiskunnallisessa keskustelussa ja koulutuspoliittisessa päätöksenteossa on lähinnä tarkasteltu teknologista kehitystä, muuttuneita tuotantomalleja ja työelämän muuttuneita tiedon tarpeita. Sen sijaan aikuisen ihmisen omiin tarpeisiin ymmärtää minuuttaan, omaa henkistä kasvuaan ja muutostaan, on kiinnitetty varsin niukasti huomiota.

Jotta voisimme ymmärtää yksilön kehitystä ja muutosta, tulee hänen tavoitteitaan, kokemuksiaan ja toiveitaan tarkastella suhteessa tiettyyn aikaan ja kulttuuriin. Tämän päivän länsimaista yhteiskuntaa on kuvattu ja luonnehdittu erilaisia käsitteitä käyttäen. Analyyseihin liittyy myös yhtäläisyyksiä. Ulrich Beck kuvaa "riskiyhteiskuntaa" (1986), Zygmunt Bauman "postmodernia" (1991) ja Anthony Giddens "jälkitraditionaalista" yhteiskuntaa (1991). Analyyseissa erilaiset riskit, epävarmuudet ja traditioiden häviäminen tuovat mukanaan jatkuvasti muuttuvia valintatilanteita, joissa on vaikea suunnistaa ja joissa joudutaan ristiriitaisen informaation ja varman tiedon puutteesta huolimatta kriittisesti tarkastelemaan ja kyseenalaistamaan omaa näkökantaa.

Ulrich Beckin (1994) mukaan modernin yhteiskunnan "yksilöllistymisprosessi" tarkoittaa juuri sitä, että kaikki määrittely-yritykset, jopa minän määrittely, siirtyvät yksilön itsensä tehtäväksi. Kun samanaikaisesti kulttuurisiksi arvoiksi nousevat nuoruuden, terveyden, tehokkuuden ja menestyksen ihannointi, luodaan perspektiivi joka pitää etäisyyttä vanhenemiseen, kärsimykseen ja kuolemaan. Kysymykseksi nousee se, miten moderni ihminen määrittelee minuuttaan, jos hän esimerkiksi sairastuu tautiin, joka saattaisi johtaa kuolemaan, ja ympäristössä vallitsevat ihanteet tuntuvat katoavan omasta minuudesta?

Pohdin tässä artikkelissa sitä, miten ihminen hahmottaa eri vaiheita elämässään? Minkä merkityksen hän antaa esimerkiksi kohtalokkaille kokemuksille ja miten nämä vaikuttavat minuuden olemukseen ja omaan elämänkertomukseen?

Artikkeli koostuu neljästä

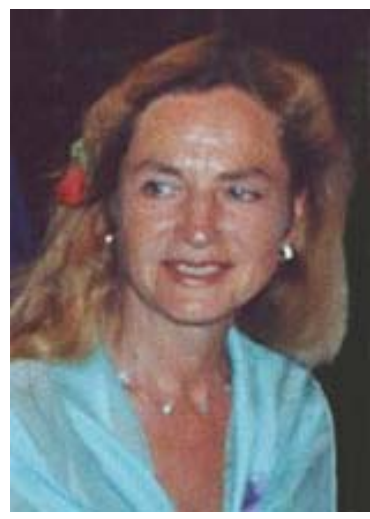

Camilla Kovero osasta. Taustana tuon esille muutamia keskeisiä lähestymistapoja tarkastella minuuden olemusta, toisessa osassa käsittelen minuutta ja sen muutosta elämänkertomusten avulla, osassa kolme kuvaan minuuden kriisiä ja muutosta kohtalokkaina hetkinä, päätösosassa teen lyhyen yhteenvedon ja nostan esille elinikäisen oppimisen haasteita tämän päivän riskiyhteiskunnassa.

\section{MINUUDEN OLEMUS}

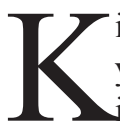
iinnostus minuuteen ei ole uusi ilmiö. Sen ymmärtäminen, persoonallisuuden ja

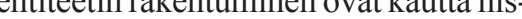
torian kuuluneet filosofian keskeisiin kysymyksiin. Suuret ajattelijat, kuten Augustinus ja myöhemmin Tuomas Akvinolainen, ovat tuoneet länsimaiseen ajatteluun käsityksen syvästä minuudesta, minuuden henkisestä ja sisäisestä olemuksesta. Myöhemmin minuutta, itsetuntemusta ja identiteettiä on kuvattu ja määritelty niin filosofisesta kuin psykologisesta ja sosiologisesta pers- 
pektiivistä käsin. Ei löydy yhtä kiistatonta lähestymistapaa minuuden olemuksen arviointiin ja itsetuntemuksen analysointiin. Toisaalta kehityspsykologinen kirjallisuus tukee käsitystä minuuden harmonisesta kehityksestä, jonka perustana on jatkuvuus, muuttumaton ydin ja pysyvät arvot (esim. Stern \& Alexander 1977, Hewitt 1989). Toiset teoriat korostavat minuuden syvyyttä, moniulotteisuutta ja muutosta sekä sitä, miten minuuden kehitystä on mahdollista ymmärtää arvojen tiedostamisen ja minuuden narratiivisten ominaisuuksien avulla (Giddens 1991, McAdams 1996, Taylor 1989, Puolimatka 2002).

Charles Taylor $(1989,1995)$ tuo esille minuuteen liittyvien kysymysten ontologisen luonteen, tavan orientoitua elämään ja sen yhteyden minuuteen. Identiteetti rakentuu tai määrittyy sen mukaan, mikä jokaisessa yksittäisessä velvoitteessa tai tehtävässä arvioidaan hyväksi ja arvokkaaksi: mikä ansaitsee ihailua tai toisaalta halveksuntaa, mikä on ihmiselle tärkeää tai arvokasta, mikä on mielekästä ja mihin ihminen kuuluu? Tämä lähestymistapa tuo esille sosiaalisen ympäristön ja yhteenkuuluvaisuuden merkityksen; miten minuuden ja identiteetin rakentuminen tapahtuu läheisessä vuorovaikutuksessa yhteisön kanssa. Modernista minuudesta muodostuu oma henkilökohtainen projekti, jota yksilö rakentaa itsetutkiskelun kautta. Minuudesta tai identiteetista tulee oma luomus, josta on itse myös vastuussa. Giddensin (1991) mukaan minuudesta muodostuukin refleksiivinen, organisoitu projekti, joka koostuu yhtenäisten, mutta alati muuttuvien biografisten kertomusten tai narratiivien jatkumosta.

\section{ELÄMÄNKERTOMUS JA MUUTTUVA MINUUS}

$\square$ lämänkertomusten rakentaminen mahdollistaa modernin minuuden eri elämänvaiheiden ymmärtämisen ja luo pohjan yhdistää yksilön menneisyyden nykyhetkeen ja tulevaisuuteen. Samalla oma elämänkertomus yhdistää minuuden laajempaan kulttuuriseen ja sosiaaliseen yhteyteen. Giddensin mukaan yksilön identiteetti ei löydy määrätyistä ominaisuuksista tai luonteenpiirteistä, vaan kyvystä ylläpitää henkilökohtaista narratiivia (elämänkertomusta) ja valita elämänpolitiikkaa.

McAdams (1996, 308) on haastatellut ja analysoinut yli 200 yksilön elämänkertomusta. Hän tuo esille sen, miten narratiivit mahdollistavat mi- nuuden eri elementtien yhdistämisen sekä luovat jatkuvuuden ja yhtenäisyyden tunnetta.

Elämänkertomus on psykososiaalinen rakennelma, jota yksilö luo. Samalla se on kuitenkin vahvasti sidoksissa siihen aikaan ja kulttuuriin, jossa ihminen elää.

Ari Antikaisen johtama laaja tutkimusprojekti nostaa esille suomalaisten sukupolvien oppimiskokemusten sidonnaisuuden aikakauteen ja yhteiskunnan rakenteeseen (1995). Juha Kauppila osoittaa, miten koulutuksen merkitys elämänkulun rakentajana eroaa eri sukupolvien elämänkertomuksissa. Vanhimman sukupolven ihanteellisista merkityksistä, edetään keskimmäisen sukupolven välineellisiin merkityksiin ja edelleen nuorimpien sukupolvien hyödykkeellisiin ja itsestään selviin merkityksiin (Kauppila 1996).

Elämänkertomukset perustuvat empiirisiin faktoihin (esimerkiksi "synnyn keskellä talvea helmikuun 10. päivänä vuonna 1955”), mutta ne menevät myös faktojen taakse yhdistämällä mielikuvituksellisesti menneen, nykypäivän ja tulevaisuuden mielekkääksi, ymmärrettäväksi kokonaisuudeksi.

Elämänkertomuksen ja identiteetin kehityksessä voidaan McAdamsin mukaan $(1996,310)$ erottaa kolmea vaihetta: alku, keskikohta ja loppu, esinarratiivinen-, narratiivinen- ja myöhäisnarratiivinen vaihe. Näissä elämän kannalta tärkeät ydinepisodit muodostavat lähtökohtia menneisyyden rakentamiselle. Moderniin minuuteen sisältyy usein sekä virallinen kertomus, joka on yhteydessä määrätyn roolin ja ympäristön vaatimuksiin, mutta myös epävirallinen, henkilökohtainen kertomus siitä, "kuka ihminen todella on". McAdamsin mukaan kumpikaan kertomus ei ole autenttisempi tai todellisempi kuin toinen. Sen sijaan identiteetti heijastaa "minän" pyrkimystä yhdistää minuuden virallista ja yksityistä kertomusta mielekkääksi kokonaisuudeksi. Identiteetti on "minän" ominaisuus, se on kertomus, joka pyrkii sitomaan yhteen "minän" eri alueita.

Teoriat korostavat minuuden rakentumisen prosessinomaista luonnetta ja sitä, miten elämänkertomukset mahdollistavat minuuden eri vaiheiden ymmärtämisen. Teoriat eivät kuitenkaan tarkastele minuuden muutosta tai sitä, mitä muutosprosessissa tapahtuu. Minuuden muutosta voidaan verrata J. Mezirowin $(1991,192)$ teoriaan "transformatiivisesta" oppimisesta, ja Grimmetin ja muiden (1990) käsityksiin siitä, miten muuttuneet toimintateoriat edellyttävät kriittistä ref- 
lektointia (Kovero 1999). Oppiminen tapahtuu lisääntyneen itsetuntemuksen ja muuttuneiden merkitysnäkökenttien tai muuttuneiden perspektiivien tuloksena. Merkitysnäkökenttien muutokseen sisältyy olennaisesti aikaisemman kokemuksen rekonstruointi, joka syntyy omien uskomusten ja ongelmaratkaisumallien kriittisen reflektoinnin tuloksena. Perspektiivit tai merkitysnäkökentät saattavat muuttua, kun tilanne joskus yhtäkkiä pakottaa meidät peruskäsitystemme ja niin sanottujen "itsestään selvyyksien" uudelleen arviointiin, esimerkiksi kohtalokkaina hetkinä. Muuttuneet perspektiivit voivat johtaa päätökseen tehdä huomattavia elämänmuutoksia.

Tod Sloan (1986) kyseenalaistaa humanistiseen psykologiaan liittyvää käsityksiä psykologisen kasvun joko itsestään selvästä, luonnonmukaisesta tapahtumasta tai vaiheittaisesta määrättyihin elämän kriiseihin (esimerkiksi Eriksonin teoria) liittyvästä kasvusta ja kehityksestä. Sloan on analysoinut huomattavia elämänpäätöksiä tehneiden aikuisten elämänkertoja. Hän toteaa, että kasvu ja kehitys syntyvät minuuden reflektoinnin ja ympäristön vuorovaikutuksen tuloksena. Hänen käsityksensä on verrattavissa Mezirowin näkemykseen perspektiivien muutoksesta elämän päätöksissä.

Tämän päivän riskiyhteiskunnassa nousee minuuden muutos tärkeäksi kysymykseksi. Mitä tapahtuu esimerkiksi elämän kriisin aikana: miten minuuden olemus muuttuu, jos jatkuvuudentunne katoaa, integraatio hajoaa ja yhteenkuuluvaisuuden tunne muuttuu tai häviää? Elämän kriisi voi esimerkiksi laueta "kohtalokkaan hetken" seurauksena (Giddens 1991). Näitä hetkiä ja kokemuksia luonnehtii se, että arjen perusta yhtäkkiä muuttuu. Tunne siitä, että "kaikki on niin kuin tavallisesti", katoaa ja perusturvallisuus hajoaa. Hetket voivat syntyä (lääkärintarkastuksen tulosten seurauksena) ympäristöstä saadusta informaatiosta, esimerkiksi lääkärintarkastuksen tulokset ovat järkyttäviä. Kriisin laukeamiseen liittyy yllätyksellisyys, yksilö kokee elämänsä uhatuksi odottamattoman kokemuksen seurauksena.

\section{MINUUDEN KRIISI JA MUUTOS KOHTALOKKAINA HETKINÄ}

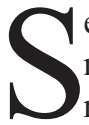

euraavassa tarkastelen minuuden kriisiä ja muutosta kohtalokkaiden kokemusten seurauksena. Tarkastelu perustuu kahdeksantoista naisen elämänkerralliseen tutkimukseen
(Kovero\& Tykkä 2002, Kovero 2003). Tavoitteena oli analysoida rintasyöpää sairastaneiden naisten kokemuksia siitä, miten sairastuminen vaikutti elämään, minuuden olemukseen, omiin arvoihin, tavoitteisiin ja elämänvalintoihin.

Koska tavoitteena oli kuvata ja ymmärtää naisten kokemuksia elämismaailmastaan sairastuessaan rintasyöpään, oli tutkimuksen lähestymistapa fenomenologinen. Elämismaailma kuvaa subjektin ja maailman välistä suhdetta. Vaikka on kysymys jaetusta objektiivisesta maailmasta, elämismaailma on kuitenkin sidoksissa subjektiin, hän kokee elämismaailman ja toimii siinä. Jotta voisi ymmärtää, minkä tarkoituksen tai merkityksen yksilö antaa eri kokemuksille ja tapahtumille elämässään ja miten nämä ovat vaikuttaneet hänen ajatuksiin, arvoihin ja tavoitteisiin, tarvitaan fenomenologista lähestymistapaa (Husserl 1995, Schutz 1967). Silloin on pyrkimys ymmärtää yksittäisten henkilöiden ja sosiaalisten ryhmien suhdetta ympäristöön, sitä koettua maailmaa, jossa he elävät ja toimivat (Bengtsson 1998, Van Manen 1990).

Kertomukset osoittavat, miten vakava sairastuminen vaikutti naisten elämään. Kohtalokas sattumanvarainen tapahtuma herätti voimakkaita ahdistuksen ja toivottomuuden tunteita. Naiset käsittelivät kriisitilannetta hakemalla tukea ympäristöstä ja kertomalla sairastumisesta läheiselle henkilölle. Kertomukset osoittavat, miten läheisen ihmisen tuki voi lievittää tuskaa ja lohduttaa, mutta myös sen, miten läheisen empatia ja lämpö ei ole itsestäänselvyys. Osa naisista jäi ilman tukea, he kohtasivat jopa välinpitämättömyyttä ja kylmyyttä.

Pelko ja ahdistus taudin uusimisesta kuului naisten arkeen. He etsivät voimia ja vahvuutta minuudestaan tehdäkseen elämänpäätöksiä. Muutama nainen kertoo, miten elämä jatkui kuten aikaisemmin, arkipäivän rutiinit ja miehen tuoma tuki auttoivat heitä. Vaikka kaikki eivät kokeneet, että elämä itsessään muuttui, useammat kertoivat, miten kokemus muutti heitä ihmisenä. Lisääntynyt itsetuntemus ja uudet ihanteet johtivat oman itsensä sekä myös menneisyyden että tulevaisuuden uudelleen arviointiin. Toiset turvautuivat traditionaalisiin auktoriteetteihin ja tuttuihin toimintamalleihin, jotkut tekivät huomattavia elämänmuutoksia. Naiset kokivat aikuistuvansa ja kypsyvänsä ihmisenä. Suvaitsevaisuus, empatia ja ymmärrys sekä itseään että muita kohtaan lisääntyi. 
Tärkeiden elämäntavoitteiden menettäminen herätti surua, siitä huolimatta naiset ovat toiveikkaita. He kokevat ymmärtävänsä paremmin omaa minuuttaan ja tiedostavansa, mikä elämässä on tärkeätä. He tuovat esille, miten tärkeätä on tiedostaa ja tuoda ilmi myös vaikeita tunteita, ahdistusta ja tuskaa, vaikka ympäröivä kulttuuri suhtautuu torjuvasti tuskalliset tunteiden ilmaisemiseen.

Kertomukset osoittavat, miten kohtalokas kokemus muutti naisten arvoja ja käsityksiä hyvästä elämästä. Tärkeintä oli nyt itse elämä, arkinen elämä, työnteko ja läheiset, luottamukselliset suhteet. "Itsestäänselvyydet" nousivat näkyviksi ja saivat uuden arvon. Hyvään elämään kuului kyky elää "tässä ja nyt", mutta myös toivomuksia tulevaisuudesta. Toiveita tukea ja seurata lasten kehittymistä sekä toiveita jakaa omaa kokemusta muiden kanssa.

\section{YHTEENVETO}

Jatkuvan muutosvalmiuden, mutta puuttuvan muutossuunnan ristiriidassa yksilöt joutuvat itse määrittelemään minuuttaan, valitsemaan "elämänpolitiikkaansa" ja tuottamaan omaa elämänkertomustaan. Moderni minuus on turvaton ja altis kriiseille. Elämänkertomukset osoittavat, miten kohtalokas tapahtuma keskeyttää tavallisen elämän ja olemassaolon itsestään selvyyden. Arjen rutiinit hajoavat, perusturvallisuus katoaa, syntyy pelon ja toivottomuuden tunteita. Tapahtuma saattaa johtaa kriisiin ja omien arvojaan ja ihanteiden kyseenalaistamiseen. Jos minuuden ja identiteetin perusta muodostuu tavasta orientoitua elämään, tavasta arvioida, mikä on hyvää ja arvokasta sekä omista arvoista ja valinnoista (vertaa Taylor ym.), näiden kyseenalaistaminen merkitsee minuuden perustan horjumista. Minkälaisia välineitä ihmisillä on tämän päivän "riskiyhteiskunnassa" selviytyä elämän ja minuuden kriisistä?

"Vanhassa" yhteiskunnassa elämää ohjaavat arvot ja traditiot tulivat ulkoapäin annettuina, elämänkriisi saattoi syntyä yksilön valintojen ja ympäristön asettamien vaatimusten ristiriidasta (sovittamattomuudesta). Erona tämän päivän länsimaiseen kulttuuriin oli se, että "vanhassa" yhteiskunnassa syvään minuuteen liittyvät arvot eivät olleet vieraita. Kulttuurinen perspektiivi ei pitänyt etäisyyttä hengellisyyteen, kärsimykseen ja kuolemaan. Ehkäpä ihmisen valmiudet kohdata kriisejä ja mahdollisuudet saada tukea ympäristöstä silloin olivat paremmat. Myöhäismodernissa yhteisössä, missä yksilö itse rakentaa tulevaisuuttaan omien valintojen kautta, kriisi saattaa merkitä sekä omien arvojen että ympäristössä vallitsevien ihanteiden kyseenalaistamista. Ympäröivä kulttuuri ei tarjoa tukea eikä välineitä käsitellä ahdistusta, yksinäisyyttä ja kuolemanpelkoon liittyviä tunteita. Varsinkin tilanteissa, jossa sosiaalinen tuki on puutteellinen ja ulkoiset tekijät, kuten ongelmat parisuhteessa tai huoli pienistä lapsista, vielä lisäävät stressiä, voi kriisin käsittely tuntua ylivoimaiselta ja johtaa kohtalokkaisiin seurauksiin.

Ihmiset kokevat elämänkriisit eri tavalla. Selviytyminen vaikeasta tilanteesta näyttäisi vaativan jonkinlaista päätöksentekoa, toisin sanoen mahdollisuuksia, uskallusta ja sisäistä vahvuutta arvioida omaa elämää. Ratkaisevaa saattaisi olla se, miten yksilö kokee vahvuutensa suhteessa ympäristöön juuri kriisitilanteessa. Elämänkertomukset osoittivat, miten päätöksiä edelsi minuuden reflektointi ja oman sisäisen vahvuuden analysointi. Päätösprosessi on verrattavissa Mezirowin näkemykseen "transformatiivisesta" oppimisesta (19991), jossa oppiminen tapahtuu lisääntyneen itsetuntemuksen ja muuttuneiden perspektiivien seurauksena.

Kohtalokkaasta kokemuksesta muodostuu uusi vaihe elämässä, uusi ydinepisodi (McAdams 1996), joka muuttaa elämänkertomusta. Kertomukseen syntyy uusia ihanteita ja tavoitteita. Perspektiivi muuttuu ja suuntautuu omiin arvoihin ja siihen, "kuka todella olen". Pyrkimyksenä yhdistää minuuden eri elementtejä ja luoda yhtenäisyydentunnetta moderni minuus näyttää muuttuvan syvän minuuden kaltaiseksi.

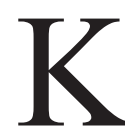

uten alussa totesin, nykypäivän länsimaisen kulttuurin ihmiskäsitystä hallitsee nuoruuden, vahvuuden ja järjen ihanteet, samalla elinikäisen oppimisen kysymyksiä tarkastellaan lähinnä viranomaisten ja elinkeinoelämän tarpeita huomioiden. Nämä perspektiivit eivät tarjoa tukea elämänkriisin aikana. Ne tuntuvat sekä etäisiltä että vierailta.

Vaikka yhteiskunnan "yksilöllistyminen" toisaalta merkitsee vapautta, merkitsee se myös samalla pakkoa valita "elämänpolitiikkaa" ja tuottaa omaa elämänkertomusta. Yksilön ihanteet, valinnat ja toimintatavat eivät tapahdu tyhjössä, vaan ovat sidoksissa yhteisöön, jossa hän elää. 
Yhteisön kehityksen kannalta onkin ratkaisevaa, että sen jäsenillä on sekä kykyä valita vaihtoehtoisia toimintamalleja että myös tahtoa vaikuttaa ympäristön dynamiikkaan.

Myöhäismodernin yhteiskunnan aikuiskasvatukselliset haasteet koskevat keskeisiä pedagogisia teemoja, kuten yksilön ja kollektiivin välistä suhdetta sekä minuuden ja identiteetin olemusta. Kysymyksiksi nousee: miten tukea ja edistää kriittistä ajattelua ja kykyä reflektoida omaa tietoisuutta? Tavoitteena on syventää itsetuntemusta ja itseohjautuvuutta ja siten mahdollistaa toimintakykyisyyden kehittymistä ja uusien merkitysnäkökenttien avautumista.

\section{LÄHTEET}

Antikainen, A., Houtsonen, J., Huotelin, H. \& Kauppila, J. (1995). In search of the meaning of education: the case of Finland. Scandinavian Journal of Educational Research. 39, no. 4, 295-309.

Bauman, Z. (1991). Modernity and ambivalence. Cambridge: Polity Press.

Beck, U. (1986). Risikogesellschaft. Auf dem Weg in eine andere Moderne. Frankfurt: Suhrkamp.

Beck, U., Giddens, A. \& Lash, S. (1994). Reflexive modernization. Politics, tradition and aesthetic in the modern social order. Cambridge: Polity Press.

Bengtsson, J. (1998). Fenomenologiska utflykter. Människa och vetenskap ur ett livsvärldsperspektiv. Uddevalla: Media Print.

Giddens, A. (1991). Modernity and self-identity: Self and society in the late modern age.

Stanford University Press.

Grimmet, P., Erickson, G. L., Mackinnon, A.M. \& Ricken, T.J. (1990). Reflective practice in teacher education. Teoksessa: Encouraging reflective practice in education. Clift, T., Houston, R., Pugach, M. (red.) New York: Teacher college press. 20-38.

Hewitt, J. P. (1989). Dilemmas of the American self. Philadelphia: Temple University press.

Husserl, E. (1995). Fenomenologian idea. Viisi luentoa. Loki-Kirjat.

McAdams, D. P. (1996). Personality, modernity, and the storied self: A contemporary framework for studying persons. Psychological Inquiry. 7, no. 4, 295-321.
Mezirow, J. (1991). Transformative dimensions of adult learning. San Francisco: Jossey-Bass.

Kauppila, J. (1996). Koulutus elämänkulun rakentajana. Teoksessa Antikainen, A. \& Huotelin, H. (red.) Oppiminen ja elämänhistoria. Aikuiskasvatuksen 37. vuosikirja.

Kovero, C. (1999). Muutos ja oppiminen työterveyshuollossa. Aikuiskasvatus 4, 352-357.

Kovero,C \& Tykkä, E. (2002). Att insjukna i bröstcancer. Vård $i$ Norden 22, no.3, 15-20.

Kovero, C. (2003). Självet i förändring i relation till omskakande eller ödesdigra erfarenheter. Käsikirjoitus lähetetty Nordisk Pedagogik julkaisuun marraskuussa 2003.

Puolimatka, T. (2002). Opetuksen teoria konstruktivismista realismiin. Tammi.

Schutz, A. (1967). The phenomenology of the social word. Evanston: Northwestern University.

Sloan, T. S. (1987). Deciding self-deception in life choices. New York: Methuen.

Stern, H. \& Alexander, R. (1977). Cohort, age and time of measurement: Biomorphic considerations. Teoksessa: Life-span developmental psychology: Dialectic perspectives on experimental research. Datan, N. \& Reese, H. (red.) New York: Academic Press.

Taylor, C. (1989). Sources of the Self. The Making of the Modern Identity. Cambridge Uni-versity Press.

Taylor, C. (1995). Identitet, frihet och gemenskap. Politiska-filosofiska texter i urval och med inledning av Harald Grimen. Göteborg: Daidalos.

Van Manen, M. (1990). Reseaching lived experience. Human science for an action sensitive pedagogy. State University of New York press.

Artikkeli saapui 28.2.2003. Se hyväksyttiin julkaistavaksi toimituskunnan kokouksessa 15.3.2004. 